\title{
Nota de Opinión: Buscando los virus del sarampión y la rubéola y que lo mejor no sea enemigo de lo bueno
}

Carlos García* , Jerónimo Cello**

Recientemente cayó en mi bandeja de entrada un proyecto de un estudio piloto conducido por el Departamento de Epidemiología del Gobierno de la Ciudad de Buenos Aires "para la búsqueda activa de casos sospechosos de Sarampión, Rubéola y Síndrome de Rubéola Congénita (SRC) en la Ciudad de Buenos Aires'.

No digo que éste sea el caso, pero siempre que leo "planes", "programas", "políticas de Estado", "experiencias de campo" y un montón de nombres más, destinados a "encantar serpientes" con títulos pretenciosos y un poquito grandilocuentes, lo primero que se me pasa por la cabeza es desconfiar. Por otro lado, también sé que "lo mejor es enemigo de lo bueno" como me decía un ex amigo calificando mi escepticismo y diciéndome que si fuera por mí, con este ánimo de querer siempre hacer las cosas "mejor", no haría nada. Algo de razón tenía; si fuera político estaría tan deprimido en esas oficinas plagadas de intereses personales, de negociados, de sindicalistas corruptos, de acróbatas del poder, de saltimbanquis, de "vendedores ambulantes de espejitos de colores" con el único fin del sobrecito por debajo de la mesa, que seguramente, le pediría a mi joven asistente informático (contratado "part-time" en negro y por unos pocos pesos) que me instale un buen solitario en la PC y dejaría para mañana lo que no puedo hacer hoy, ni nunca.

Es cierto, muchas veces caemos en la "parálisis por análisis" en "la duda es jactancia de intelectuales" (Coronel Aldo Rico dixit - Monte Caseros 1988) y no hacemos nada. Por el contrario, los políticos entran con un elefante en el bazar, ensordecedor ruido de cristales, gritos, platos rotos, pu tum, pa tam... y terminan haciendo. De ahí, nuestra temida frase criolla "Roban pero hacen".

Pero, no viene al caso, no dudemos de todo y volvamos a lo nuestro. Leo eso del "Estudio piloto para la búsqueda..." y (lo mejor, enemigo de lo bueno) me pregunto varias cosas:

1. ¿Para qué hacer un estudio piloto? Es decir, qué le pedimos al estudio piloto.

2. ¿Nos responderá la pregunta el estudio piloto?

3. Si nos responde la pregunta ¿Tomaremos medidas para cambiar el rumbo?

4. ¿Será correcta la metodología del estudio piloto?

5. ¿Será costo-efectiva? (es decir: vale lo que cuesta).

6. ¿Haremos algo, después de "cosechar" lo sembrado en el estudio piloto? Es decir ¿Implementaremos medidas tendientes a corregir el problema?

7. ¿Podremos afrontar esas medidas?

Se me ocurre, por el título del trabajo, que el problema subyacente que movilizó a nuestros epidemiólogos-políticos será la prevalencia de población no inmunizada (susceptible) contra estas enfermedades con la consecuente morbi-mortalidad por las mismas y la presunta necesidad de adoptar medidas correctivas cuyo resultado sería minimizar esta morbi-mortalidad, como el síndrome de rubéola congénita.

El paso siguiente fue leerme el proyecto. Entre los justificativos estaban, como era de esperar, las brechas de detección y de notificación, la presencia de áreas "mudas" de notificación de casos sospechosos, problemas de obtención de datos, problemas operativos, etcétera.

El objetivo general del estudio es la determinación de la circulación local de virus salvajes de sarampión y rubéola mediante la búsqueda activa de enfermedades febriles eruptivas y de casos de síndrome de rubéola congénita en residentes asistidos en efectores seleccionados de la Ciudad Autónoma de Buenos Aires.

Los objetivos específicos del estudio son

1- Identificar casos sospechosos de enfermedades febriles eruptivas (EFE) y SRC asistidos en los efectores seleccionados.

2- Verificar su inclusión en el sistema de vigilancia de EFE y SRC.

3- Investigar los casos sospechosos no registrados o incompletamente estudiados.

4- Efectuar evaluación por laboratorio de los casos sospechosos no registrados o los no investigados.

La metodología consiste en la "búsqueda activa", es decir la pesquisa intencionada de casos sospechosos mediante la revisión de registros con diagnósticos compatibles con las manifestaciones clínicas de sarampión y SRC.

Anexan el protocolo, definiciones, planillas y formularios bastante prolijitos.

Es decir, nuestras autoridades sanitarias se proponen "ir a buscar al bicho a su madriguera", para después, me imagino, darle duro y controlarlo.

Me hice entonces varias preguntas: si habrá que buscar al bicho; si decidimos que hay que ir a buscarlo, cómo se debería buscarlo para estar seguros de que sabemos dónde y cómo está y que una vez que lo encontremos qué tendríamos que hacer con él.

Qué mejor, me dije, que mandárselo a mi amigo Jerónimo, a quien ya presenté en otras notas (Jerónimo Cello: Virólogo del Department of Molecular Genetics and Microbiology, Schoolof Medicine, State University of New York at Stony Brook, también experto en bioseguridad y con quien solemos comentar los accionares de nuestras autoridades sanitarias).

Como diría mi padre, "puse todo en un sobre, escribí unas líneas y se lo mandé". La respuesta no se hizo esperar:

\section{"Charly:}

Leí lo de sarampión-rubéola. Es un documento razonablemente bien escrito. Pero hay algo fundamental que no se tiene en cuenta. El objetivo del provecto es el siguiente: "Determinar la circulación local de virus salvajes de sarampión y rubéola mediante la búsqueda activa de EFE y de casos de SRC en resi-dentes asistidos en efectores seleccionados de la C.A.B.A". Noble el objetivo. Pero si buscás circulación, hay que tener en cuenta que el virus circula en forma asintomática o con síntomas incaracterísticos en un porcentaje de la población. Para el caso de la rubéola el mismo documento dice que hasta el $50 \%$ de los pacientes que padecen rubéola pueden ser asintomáticos pero infectantes. Con respecto al sarampión, hay muchísimos casos asintomáticos o leves y la población vacunada e inmunizada se reinfecta y participa de la cadena de transmisión. Es decir, si el objetivo es buscar circulación indirectamente mediante la detección de casos clínicos, los resultados obtenidos pueden ser muy sesgados. La definición de casos sospechosos, confirmados, compatibles y definitivos tal vez lleve a obtener datos muy alejados de la realidad. Viendo los casos de Argentina y por haber ido a la charla que dio la gente del Ministerio de Salud sobre este tema en el $X$ Congreso Argentino de Virología (yo participé de la mesa porque trataban polio también), la mayoría de los casos fueron importados y produjeron muy pocos casos locales, lo que indica que la población en general está bien protegida. Tal cual dice el documento que me mandaste, hay una cobertura administra-

Médico de Familia del Hospital Italiano de Buenos Aires carlos.garcia@ hospitalitaliano.org.ar

Virólogo del Department of Molecular Genetics and Microbiology, School of Medicine, State University of New York at Stony Brook 
tiva alta, de alrededor del 95\%, pero puede haber grupos de bajo nivel socioeconómico, que viven hacinados y no están vacunados. En esos ámbitos, el virus puede circular y generar brotes, pero el efecto rebaño, limita la llegada del virus y protege a los no vacunados. La mayoría de los casos en los últimos años en Argentina, si recuerdo bien, han sido en individuos de clase media 0 alta que no se quisieron vacunar o extranjeros.

Entonces en mi opinión, desde el punto de vista de la salud pública y sin dejar de reconocer este estudio, lo más importante sería:

1) Hacer estudios serológicos en poblaciones de diferentes niveles socioeconómicos para saber el verdadero nivel de protección que tiene la población contra esos virus, principalmente en personas de nivel socio económico bajo donde si el virus llega producirá brotes y habrá mayor morbimortalidad. En clase media o alta hay en algunos casos una tendencia a no vacunarse. Son del movimiento anti-vacuna pero la entrada en comunidades como esa genera casos aislados.

2) Entrenar a los médicos a diagnosticar estas enfermedades exantemáticas. 3) Identificar a los no vacunados mediante registros y/o estudios serológicos y vacunarlos.
Para mí, como está planteado el estudio, el objetivo tendría que ser algo así como "Determinar la incidencia de sarampión y rubéola..." La determinación de la circulación en mi opinión se logra mediante aislamiento del virus o PCR de sintomáticos y asintomáticos.

Jerónimo.

P.D. Me olvidaba. No pocos de los que adquieren sarampión son médicos y enfermeras que atienden a pacientes afectados. Por lo que también habría que hacer serología del personal de salud, ver el status quo y vacunarlos o directamente vacunarlos a todos. Pero no sé la costo-efectividad de esto."

Resumiendo: la idea no está mal, el diseño podría ser mejor y, como siempre, si nuestras autoridades (civiles, militares y eclesiásticas como se decía antes ante tan honrada presencia en los actos públicos) se asesoraran con gente que sabe mucho, las cosas se harían mucho mejor sin que lo mejor sea enemigo de lo bueno.

Y colorín colorado, este cuento ha terminado.

Garcia C, Cello J. Buscando los virus del sarampión y la rubéola y que lo mejor no sea enemigo de lo bueno. Evid Act Pract Ambul. Oct-Dic $2011 ; 14(4): 124-125$.

\section{Referencias}

1. Estudio Piloto para la búsqueda activa de casos sospechosos de Sarampión, Rubéola y Síndrome de Rubéola Congénita en la Ciudad de Buenos Aires. Dra. Mónica Valenzuela y Dr. Raúl Forlenza. Departamento de Epidemiología del Ministerio de Salud del Gobierno de la Ciudad de Buenos Aires.

Nota: las opiniones vertidas en esta sección no necesariamente representan la opinión del Comité de Redacción de Evidencia, sino solamenete la de los autores. 